\title{
Lichens as a source of chemical compounds with anti- inflammatory activity
}

\author{
ELŻBIETA STUDZIŃSKA-SROKA*, ADRIANNA DUBINO
}

Department of Pharmacognosy

Poznan University of Medical Sciences

Święcickiego 4

60-781 Poznań, Poland

* corresponding author: e-mail: ela_studzinska@op.pl

\section{Summary}

Symptoms of inflammation accompany a number of diseases. In order to mitigate them, folk medicine has used a variety of medicinal substances, including herbs and mushrooms. Lichens are less known organisms, containing specific secondary metabolites with interesting biological properties. One of their biological actions is the anti-inflammatory activity that has been confirmed by in vitro and animal studies. It has been proven that compounds and extracts from lichens inhibit the enzymes involved in the inflammatory process. The following paper is a review of research on the little-known anti-inflammatory properties of lichens.

Key words: lichen compounds, lichen extracts, biological activity

\section{INTRODUCTION}

Inflammation, a defense mechanism which aims at repairing damage caused in the body, accompanies a number of diseases. In case of inflammation, biochemical changes leading to redness, swelling, itching, pain, and increased temperature occur [1]. These symptoms are an easy-to-spot signal of impairment of normal functioning of the body and the disruption of existing homeostasis. Controlling, among others, the operation of enzymes that regulate the formation of pro-inflammatory cytokines and interleukins, which play an important role in the development of inflammation, fever or pain, may be beneficial. To improve health, traditional medicine has made use of natural resources for a long time. The plants have been used the most frequently, however, the substances obtained from fungi and animals have also been of significance. Lichens are an interesting taxonomic group; the organisms composed of cells of algae and 
fungi producing specific compounds, rare among the substances of natural origin, belong to this group. Their various biological properties include antimicrobial activity, known for a long time, as well as, researched in recent years, antioxidant and antitumor properties, resulting in inhibiting enzymes, antidiabetic, analgesic and anti-inflammatory activities $[2,3]$. The following paper is a review of the research on the little-known anti-inflammatory properties of lichens, drawing attention to the diversity of lichen substances, and effect of the individual compounds and extracts, whose inhibitory effect on the inflammatory processes was confirmed in vitro and in vivo.

The following electronic English databases were searched: PubMed, Scopus and Google Scholar from 1974 up to 2017. The publications have been searched by the title and abstract using the following search terms: anti-inflammatory activity, interleukin, cyclooxygenase, lichens metabolites, lichens constituents. For the selection of the manuscripts, two independent investigators (ESS and AD) assessed all the titles and abstracts.

\section{Anti-inflammatory activity of secondary meta- bolites}

\section{Depsides and depsidones}

Depsides and depsidones are an interesting group of secondary lichen metabolites. The basis of their anatomy are two or more molecules of hydroxybenzoic acids linked by an ester linkage. Depsidones, in which there is also an ether linkage that differentiates both molecules, are compounds typical for lichen. The available literature data suggest that atranorin (fig. 1), depside present in thalli of different species of lichen, has anti-inflammatory properties [4]. Bugni et al. [5] studied the effect of a cyclooxygenase inhibitor. The obtained results indicate that tested depside inhibited cyclooxygenase-1 (COX-1) in a dose-dependent manner and at the concentration of $17 \mu \mathrm{g} / \mathrm{ml}$ $(45 \mu \mathrm{M})$ caused a decrease in enzyme activity by $50 \%$. The ability to block cyclooxygenase-2 (COX-2) was lower, and at the same concentration range, atranorin inhibited the enzyme activity by $40 \%$. In this case, there was no dose-dependent enzyme - atranorin relation. The reference substance was acetylsalicylic acid, which, at the concentration of $50 \mu \mathrm{M}$, inhibited COX-1 (59\%) and COX-2 (42\%) [5]. The results of other studies indicate that atranorin, by inhibiting 5-LOX, inhibited the biosynthesis of leukotriene B4 (LTB4) in polymorphonuclear cells of bovine leukocytes ( $\left.\mathrm{IC}_{50} 6 \mu \mathrm{M}\right)$ as well, which suggests antiinflammatory properties of the compound [6]. Ingólfsdóttir et al. [7] found, however, that the degree of the inhibition of 5-lipoxygenase (5-LOX) (from porcine leukocytes) was not significant for atranorin. In a test on cyclooxygenase (microsomes from sheep seminal vesicles), the tested depside proved to be inactive [7]. The anti-inflammatory activity of atranorin was also determined in experiments on animals. The substance was administered orally to three tested groups (at doses of 50, 100, and $200 \mathrm{mg} / \mathrm{kg}$ ) one hour before the administration of $1 \%$ solution of carrageenan to the right hind paw of the rats. The positive control was acetylsalicylic acid (300 mg/kg p.o.). The results, read three hours after the carrageenan injection, showed that atranorin administered at a dose of $100 \mathrm{mg} / \mathrm{kg}$ decreased the inflammation by $29.3 \%$ and at $200 \mathrm{mg} / \mathrm{kg}$ by $32.9 \%$; acetylsalicylic acid was characterized by stronger activity (76.4\%). In the following part of the experiment, the influence of atranorin $(50,100$ and $200 \mathrm{mg} / \mathrm{kg})$ on the leukocyte migration induced in mice by intraperitoneal administration of carrageenan ( $500 \mu \mathrm{g} /$ peritoneal cavity) was assessed. Four hours after the inclusion of a substance inducing inflammation, the inhibition rate was $31.9 \%, 35.9 \%$, and $42.5 \%$, respectively. The reference substance was dexamethasone injected subcutaneously $(2 \mathrm{mg} / \mathrm{kg})$; it inhibited the migration of leukocytes at the site of inflammation by $92.2 \%$. The results proved the anti-inflammatory properties of atranorin. Moreover, it was stated that the depside is a safe compound, since the experiment conducted in rats showed no symptoms of sub-acute $(50 \mathrm{mg} / \mathrm{kg} /$ day for 30 days $)$ and acute $(5 \mathrm{~g} / \mathrm{kg})$ toxicity [8].

Another depside produced by certain species of lichens, whose anti-inflammatory properties were evaluated in animal experiments, is lecanoric acid (fig. 1). The compound applied intraperitoneally $(50 \mathrm{mg} / \mathrm{kg}$ ) decreased the carrageenan-induced rat paw edema. The effects of depside activity were similar, irrespective of whether they were assessed after three or five hours, and swelling decreased sequentially by $24.7 \%$ and $25.0 \%$ (acetylsalicylic acid reduced the swelling by $39.3 \%$ and $35.4 \%$, respectively). The research showed low toxicity of lecanoric acid as at $200 \mathrm{mg} / \mathrm{kg}$ after intravenous administration to mice showed no toxicity [9].

The anti-inflammatory effect of diffractic acid (fig. 1) was evaluated by testing its ability to inhibit the activity of 5-LOX (from bovine polymorphonuclear leukocytes). The test results showed that the compound, at the low concentration already $\left(\mathrm{IC}_{50} 7.6 \mu \mathrm{M}\right)$, resulted in the inhibition of LTB4 biosynthesis, leukotriene 
produced during inflammation. The same authors reported the ability to inhibit 5-LOX (isolated from bovine polymorphonuclear leukocytes) by barbatic acid. The results of the experiment show the strong inhibitory effect of the metabolite on the biosynthesis of LTB4 (IC50 7.8 $\mu \mathrm{M}$ ), which confirms its interesting properties [10].

One of the older studies reports the high activity of inhibiting the biosynthesis of prostaglandins in the rabbit kidney microsomes by the following depsides: 4-Omethylcryptochlorophaeic and merochlorophaeic acids (fig. 1) $(0.34 \mu \mathrm{M}$ and $0.43 \mu \mathrm{M}$, respectively) [11]. Also the ability of a depsidone - lobaric acid (fig. 2) to inhibit 5-LOX (isolated from porcine leukocytes) and cyclooxygenase (isolated from microsomes of sheep seminal vesicles) was assessed. The compound<smiles>COC(=O)c1c(C)cc(OC(=O)c2c(C)cc(O)c(C=O)c2O)c(C)c1O</smiles>

atranorin<smiles>Cc1cc(OC(=O)c2c(C)cc(O)cc2O)cc(O)c1C(=O)O</smiles>

lecanoric acid<smiles>COc1cc(C)c(C(=O)Oc2cc(C)c(C(=O)O)c(O)c2C)c(OC)c1C</smiles>

diffractic acid<smiles>COc1cc(C)c(C(=O)Oc2cc(C)c(C(=O)O)c(O)c2C)c(O)c1C</smiles>

barbatic acid<smiles>CCCc1cc(OC)cc(OC)c1C(=O)Oc1c(O)cc(CC)c(C(=O)O)c1O</smiles>

merochlorophaeic acid exhibited dose-dependent effects on lipoxygenase activity, determined by measuring the amount of produced 5-hydroxy-6,8,11,14-eicosatetraenoic acid (5-HETE) $\left(\mathrm{IC}_{50} 7.3 \mu \mathrm{M}\right)$. The impact on the cyclooxygenase activity was assessed by measuring the reduction in the production of prostaglandin $\mathrm{E} 2$, and the examined effect of the compound was described by the authors as insignificant $\left(\mathrm{IC}_{50} 29.2 \mu \mathrm{M}\right)$ [7]. Determining the impact of lichen substances on microsomal prostaglandin E2-1 synthase (mPGES-1) was the aim of the subsequent experiments. The purpose of this enzyme is to catalyze the conversion of prostaglandin E2 (PGE2) from prostaglandin H2 (PGH2); the mechanism of the inhibition of the enzyme activity was proposed as a strategy for treatment of pain, inflammation, and certain cancers [12].<smiles>CCc1cc(O)c(OC(=O)c2c(C)cc(OC)cc2OC)c(O)c1C(=O)O</smiles>

4-O-methylcryptochlorophaeic acid

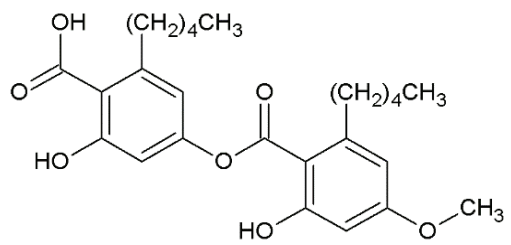

perlatolic acid

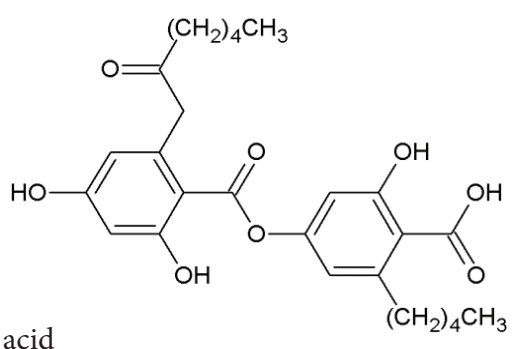

olivetoric acid

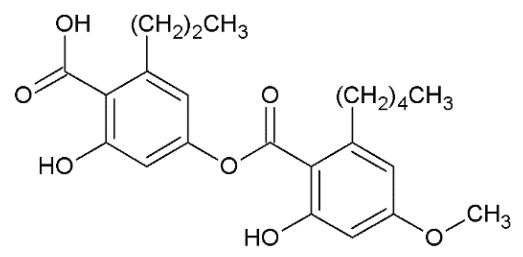

imbricaric acid<smiles>COc1cc(C)c(C(=O)Oc2cc(C)c(C(=O)O)c(O)c2)c(O)c1</smiles>

evernic acia

Figure 1.

Structural formulas of depsides 


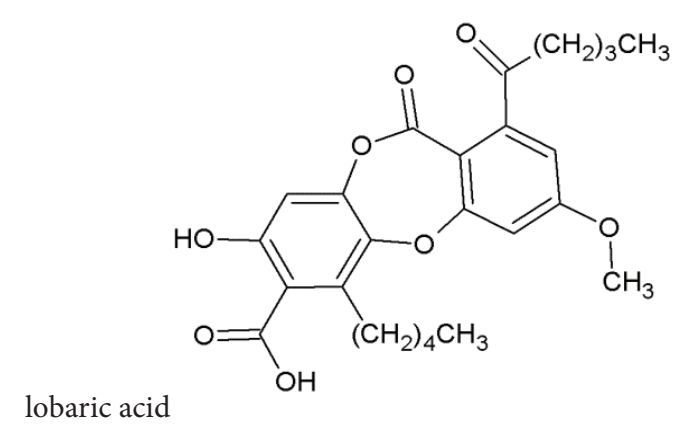

lobaric acid

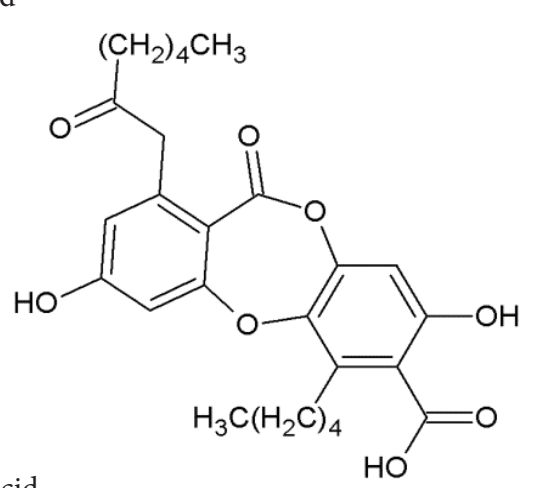

physodic acid<smiles>Cc1cc(O)c(C=O)c2c1C(=O)Oc1c(COC(=O)/C=C/C(=O)O)c(O)c(C(=O)O)c(C)c1O2</smiles>

fumarprotocetraric acid<smiles>Cc1cc(O)c(C=O)c2c1C(=O)Oc1c(CO)c(O)c3c(c1O2)C(O)OC3=O</smiles>

salazinic acid<smiles>Cc1cc(O)cc2c1C(=O)Oc1cc3c(c(O)c1O2)C(=O)OC3</smiles>

Figure 2.

Structural formulas of depsidones
The results of the study showed that a depsidone physodic acid (fig. 2) and the following despsides: perlatoic and olivetoric acids (fig. 1), significantly inhibited the enzyme ( $\mathrm{IC}_{50} 0.43 \mu \mathrm{M}, 0.4 \mu \mathrm{M}, 1.15 \mu \mathrm{M}$, respectively), stronger than the substance used as a reference - MK-886 compound ( $\mathrm{IC}_{50} 2.4 \mu \mathrm{M}$ ). This indicates the strong effect of the tested lichen substances, similar only to curcumin $\left(\mathrm{IC}_{50} 0.3 \mu \mathrm{M}\right)$ exhibiting the strongest activity among the plant compounds and stronger than other tested to date natural substances. Another tested compounds in the study: salazinic acid (a depsidone with lactone moiety) (fig. 2) and evernic acid (a depside) (fig. 1) exhibited a mild ability to inhibit synthase $(60.8 \pm 10.7 \%$ and $53.9 \pm 2.7 \%$ at the concentration of $10 \mu \mathrm{M}$, respectively), while fumarprotocetraric acid and scensidine (depsidones), variolaric acid (a depsidone with lactone moiety) (fig. 2), and methyl $\beta$-orcinol carboxylate (fig. 3) affected the enzyme activity to a small extent or showed no enzyme activity at all. The same study found moderate $\left(\mathrm{IC}_{50}>30 \mu \mathrm{M}\right)$ properties of physodic, perlatolic, and olivetoric acids to inhibit the activity of COX-1 and their lack of influence on the activity of COX-2 [13].<smiles>COC(=O)c1c(C)cc(O)c(C)c1O</smiles>

Figure 3.

Structural formula of methyl $\beta$-orcinol carboxylate

A dozen or so of lichen substances of different chemical structure have been evaluated in vitro for their ability to inhibit enzymes involved in inflammatory processes (mPGES-1 and 5-LOX) and the activation of nuclear transcription factor (NF- $\mathrm{KB})$. The results showed that among the tested compounds the following depsides: imbricaric and perlatolic acids, exhibit interesting activity (fig. 1). The analysis of the results confirmed that both compounds have a high anti-inflammatory potential as compared with those applied in reference substances research (imbricaric acid: mPGES-1 IC I0 $_{1.9} \mu \mathrm{M}$, 5-LOX IC ${ }_{50} 5.3 \mu \mathrm{M}$, NF$\kappa \mathrm{IC}_{50} 2.0 \mu \mathrm{M}$; perlatolic acid: mPGES-1 $\mathrm{IC}_{50} 0.4 \mu \mathrm{M}$,

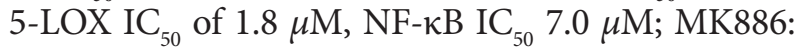
mPGES-1 IC $_{50} 2.3 \mu \mathrm{M}$; zileuton: 5-LOX in polymorphonuclear leukocytes $\mathrm{IC}_{50} 0.5 \mu \mathrm{M}$, 5-LOX $\mathrm{IC}_{50} 0.7 \mu \mathrm{M}$; parthenolide: NF- $\left.\kappa \mathrm{B} \mathrm{IC}_{50} 1.5 \mu \mathrm{M}\right)$. The authors of the study suggest that the inhibition of both enzymes (mPGES-1 and 5-LOX) provides a potentially more effective anti-inflammatory effect [14]. 


\section{Usnic acid}

Usnic acid (fig. 4) is a compound of the dibenzofuran structure, present in many lichen species, that exists in the form of two enantiomers: $(+)$ and (-); the difference is the location of the methyl group in the molecule (fig. 1). The metabolite, known for its antibacterial activity for a long time, is subject to numerous experiments which objective is the discovery of more and more aspects of the biological activity [15]. One line of the work is to study the anti-inflammatory activity of the compound, as presented by Huang et al. [16]. The results indicate that the properties of tested substance may be related to its effects on the production of inflammatory mediators. Usnic acid (at non-toxic to cells concentrations of 1.5 and $10 \mu \mathrm{g} / \mathrm{ml}$ ) incubated with stimulated with lipopolysaccharide $(10 \mathrm{ng} / \mathrm{ml})$ mouse macrophage RAW264.7 cell line, decreased the secretion of TNF- $\alpha$, IL- $1 \beta$, IL- 6 and NO (24 h incubation), as compared with control. The concentration of IL-1, tested in the supernatant of the cell culture under usnic acid treatment, was similar to that measured after activation of dexamethasone $(0.5 \mu \mathrm{m} / \mathrm{ml})$. It was also shown that tested compound, by inhibiting the activation of nuclear transcription factor NF- $k B$, may inhibit the expression of genes encoding proteins that control the inflammatory response (IL- $1 \beta$, TNF- $\alpha$, NO, iNOS, and COX-2). Usnic acid $(10 \mu \mathrm{g} / \mathrm{ml})$ also has the effect on the expression level of heme oxygenase-1 (HO-1) [16]. The results of other studies proved that $(+)$-usnic acid inhibited the synthesis of LTB4 $\left(\mathrm{IC}_{50} 42 \mu \mathrm{M}\right)$ produced during inflammation [6]. The subsequent experiments showed that the compound administered orally (25, 50 and $100 \mathrm{mg} / \mathrm{kg}$ ) inhibited the rat paw edema. At the highest dose, it worked comparably with ibuprofen $(100 \mathrm{mg} / \mathrm{kg})$ and the paw edema measured in $\mathrm{ml}$ was 0.55 for the tested substance and 0.47 for the reference substance [17]. The next study where usnic acid was tested as an anti-infammatory factor was conducted by Su et al. [18]. Authors noted that usnic acid attenuated inflammatory responses of acute lung injury in mice induced by lipopolysaccharide. It was proven that usnic acid lowered the expression of pro-inflammatory cytokines including tumor necrosis factor alpha (TNF- $\alpha$ ), interleukin-6 (IL-6) but also anti-inflammatory interleukin-8 (IL-8) and macrophage inflammatory protein-2 (MIP-2) and improved level of anti-inflammatory cytokine in the bronchoalveolar lavage fluid [18].<smiles>CC(=O)C1=C(O)C=C2Oc3c(C(C)=O)c(O)c(C)c(O)c3C2(C)C1=O</smiles>

(+)-usnic acid<smiles>CC(=O)C1=C(O)C=C2Oc3c(C(C)=O)c(O)c(C)c(O)c3[C@@]2(C)C1=O</smiles>

(-)-usnic acid

Figure 4.

Structural formulas of usnic acids

\section{Aliphatic compounds}

Substances having aliphatic structure are another, after the molecules of aromatic structure, group of lichen compounds. The (+)-protolichestrinic acid (fig. 5) has $\alpha$-methylene- $\gamma$-butyrolactone structure. In the conducted study, the impact of the activity of 5-LOX was assessed and its ability to inhibit both porcine and bovine enzyme was observed. The obtained $\mathrm{IC}_{50}$ value $-20 \mu \mathrm{M}$ and $9 \mu \mathrm{M}$, respectively for each of the tested lipoxygenases, indicated a significant anti-inflammatory potential of the tested acid [6].

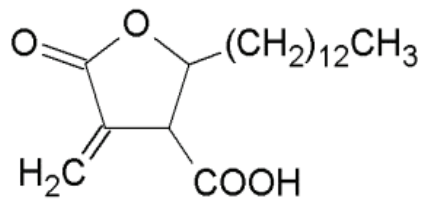

Figure 5.

Structural formula of protolichestrinic acid

\section{Polysaccharides}

The published studies have shown that some lichen polysaccharides demonstrate the anti-inflammatory effect due to alteration of the production levels of various cytokines by macrophages [19]. Omarsdottir et al. [20] examined the influence the lichen polysaccharides (Pc-1, Pc-2, Pc-3 and Pc-4, isolated from Peltigera canina) on cytokine production by rat peritoneal macrophages and rat spleen cells. The obtained results show that polysaccharides induced IL-10 secretion by rat spleen cells but not by peritoneal macrophages (IL-10 is an anti-inflammatory 
cytokine, which inhibits the synthesis of some proinflammatory cytokines). However, the examined polysaccharides induced peritoneal macrophages to induce TNF- $\alpha$ secretion (the proinflammatory cytokine) [20]. In the next study it was demonstrated that galactofumaromannans (Ths-4, Ths-5) and $\beta$-glucan (Ths-2) from Thamnolia vermicularis var. subuliformis induced rat spleen cells to secrete IL-10 at significantly higher levels than the background. This effect was not observed in the case of peritoneal macrophages [21].

\section{Anti-inflammatory activity of extracts}

Many published studies have described the biological activity of extracts obtained from thalli of various species of lichens [22]. The chemical nature of lichen secondary metabolites causes the tested extracts are generally prepared using solvents of low or medium polarity (hexane, ether, acetone, and methanol), while the aqueous extracts are tested much less frequently. The published studies on the anti-inflammatory activity of lichen were obtained in in vitro and in vivo experiments and concern different species of lichenized fungi.

The anti-inflammatory properties of Pseudevernia furfuracea, a foliose lichen of Parmeliaceae family, were checked in the carrageenan test. For the study the methanolic extract from powered thalli of lichen was prepared. The extract evaporated in vacuum was fractioned using dichloromethane, ethyl acetate and butanol saturated with water. After oral administration of the prepared extracts to mice at a dose of $100 \mathrm{mg} / \mathrm{kg}$, the right hind paw was injected with the carrageenan extract $(0.5 \mathrm{mg} / 25 \mu \mathrm{l})$. The resulting paw edema was measured every $90 \mathrm{~min}$ utes for six hours after the test substance administration. The results showed that the methanol extract reduced swelling in proportion to the elapsed time (14.6-27.5\%). Indomethacin $(10 \mathrm{mg} / \mathrm{kg})$, used as the reference substance, inhibited inflammation by about $40 \%$. Other extracts tested parallelly with P. furfuracea showed no activity. There was also no negative effect of the methanol extract on the gastric mucosa [23].

Other authors studied the anti-inflammatory activity of 17 species of lichens growing in the Alps. The conducted preliminary tests estimated the effect of the ethanol extracts on mPGES-1, 5-LOX (isolated and in polymorphonuclear leukocytes), and on the activity of the nuclear transcription factor $(\mathrm{NF}-\mathrm{\kappa B})$ in stimulated with tumor necrosis factor
(TNF- $\alpha$ ) human kidney HEK-293 cells. The obtained results showed that the extract of a lichen $\mathrm{Ce}$ trelia monachorum, belonging to the Parmeliaceae family, has the strongest activity among the tested species. The phytochemical analysis of ethanol extract from C. monachorum, meant to obtain three depsides (atranorin, imbricaric acid and perlatolic acid - the contents in the extract of imbricaric acid and perlatolic acid were determined to be $15.22 \%$ and $9.10 \%$, respectively), and eight monoaromatic derivatives (ethyl haematommate, methylbetaorcinolcarboxylate, ethyl-4-O-methylolivetolcarboxylate, ethyl olivetolate, olivetolmonomethylether, olivetol and divarinol). The results of biological investigations revealed a dose-dependent reduction in the level of PGE2 at relatively low concentrations $\left(\mathrm{IC}_{50} 2.0 \mu \mathrm{g} / \mathrm{ml}\right)$ by ethanol extract of C. monachoum. In both trials of the inhibition of 5-LOX (both isolated and in the cells), obtained $\mathrm{IC}_{50}$ values were $1.4 \mu \mathrm{g} / \mathrm{ml}$ and $1.3 \mu \mathrm{g} / \mathrm{ml}$. In addition, the extract also reduced the transactivation activity of NF- $\mathrm{KB}$ $\left(\mathrm{IC}_{50} 2.6 \mu \mathrm{g} / \mathrm{ml}\right)$, indicating a potential importance of the anti-inflammatory activity of the tested extract [14].

The anti-inflammatory properties of Parmotrema reticulatum lichen were evaluated in different animal models, using the extracts of petroleum ether, acetone, and ethanol. The phytochemical results showed the presence of steroidal constituents in the ether extract; glycosides and terpenoids in the acetone extract; in the ethanol extract glycosides and flavonoids were detected. The presence of usnic acid was confirmed by HPLC analysis only in acetone extract $(0.46 \% \mathrm{w} / \mathrm{w})$. One study was to collect newly formed granular tissue on a cotton pellet, previously placed in the cut of the lumbar spine of a mouse. Eight groups of rats (the control group, the reference group administered with indomethacin $10 \mathrm{mg} / \mathrm{kg}$, and the groups receiving 200 or $300 \mathrm{mg} / \mathrm{kg}$ of each of the extract, respectively) took part in the experiment. After eight days the pellet was removed, cleaned of granular tissue and weighed. The obtained results revealed that the best anti-inflammatory properties exhibited the acetone extract at a dose of $200 \mathrm{mg} / \mathrm{kg}$ (the weight of produced tissue was the lowest in comparison to all groups and was $5.3 \mathrm{mg}, 73 \%$ less than the control). Indomethacin worked slightly lower $(5.8 \mathrm{mg}, 70.5 \%$ of the inhibition). The ether extract showed the lowest anti-inflammatory activity (produced mass of tissue - $13.1 \mathrm{mg}, 33.5 \%$ of the inhibition). Additional studies were run in other models. The use of xylene on the outside and the inside of the right ear of mice showed that the 
ethanol extract at the concentration of $300 \mathrm{mg} / \mathrm{kg}$ exhibited the best performance (swollen ear weight was $3.8 \mathrm{mg}$, $66 \%$ less than the control). The acetone extract at the concentration of $200 \mathrm{mg} / \mathrm{kg}$ (mass of swollen ear was $4.1 \mathrm{mg}, 63.3 \%$ of the inhibition) was characterized by potent anti-inflammatory properties. The ether extract worked the weakest $(8.7 \mathrm{mg}$, the inhibition by $22.3 \%$ and $7.9 \mathrm{mg}, 29.4 \%$ of the inhibition). The studies were also carried out applying the carrageenan test. The extracts of petroleum ether, acetone, and ethanol, each at doses of 200 and $300 \mathrm{mg} / \mathrm{kg}$, were administered orally to animals, one hour before the administration of $1 \%$ solution of carrageenan to the rear paw of rats. The paw volume was assessed in 30-minute intervals after administration of the substance inducing inflammation. The results confirmed the anti-inflammatory activity of the acetone extracts $(200 \mathrm{mg} / \mathrm{kg})$ and ethanol $(300 \mathrm{mg} / \mathrm{kg})$, 120 minutes after the injection of carrageenan. The use of the extracts reduced paw edema in comparison to the control by $56.7 \%$ and $59.3 \%$ (57.6\% for indomethacin). In the following study on the antiinflammatory activity, it was assessed after subplantar injection of $0.1 \mathrm{ml}$ of a solution of histamine at the concentration of $0.001 \mathrm{mg} / \mathrm{ml}$ into the right hind paw of the mouse and oral administration of the studied extracts (petroleum ether, acetone, and ethanol - each at doses of 200 and $300 \mathrm{mg} / \mathrm{kg}$ ). The extracts of acetone $(200 \mathrm{mg} / \mathrm{kg})$ and ethanol $(300 \mathrm{mg} / \mathrm{kg})$ showed the highest percentage of the inhibition of inflammation measured after 120 minutes; they were $50.4 \%$ and $52.8 \%$, respectively. The reference substance (indomethacin, used at the concentration of $10 \mathrm{mg} / \mathrm{kg}$ ) reduced swelling by $67.2 \%$. In another study in mice, the influence of the tested extracts (200 and $300 \mathrm{mg} / \mathrm{kg}$ p.o.) on leukocyte migration induced by intraperitoneal injection of a solution of $1.5 \% \mathrm{CMC}-\mathrm{Na}+(375 \mathrm{mg} / \mathrm{kg})$ was assessed. After four hours the liquid was collected from the peritoneal cavity and the number of leukocytes was rated. The results indicated that the level of leukocytes was lower due to the usage of the ethanol and acetone extracts at the concentration of $300 \mathrm{mg} / \mathrm{kg}$ (58.35 x $10^{4}$ of leucocytes, the inhibition by $66.20 \%$ and $67.62 \times 10^{4}$ of leucocytes, the inhibition by $60.83 \%$, respectively). Dexamethasone $(20 \mathrm{mg} / \mathrm{kg}$ ) reduced the number of leukocytes by $71.89 \%$ (48.52 x $10^{4}$ of leukocytes) [24].

\section{CONCLUSION}

The analysis of the collected results shows a great therapeutic potential of the lichen extracts and metabolites. The literature data proved the antiinflammatory activity of tested until now extracts from $P$. furfuracea, C. monachorum and P. reticulatum. The compounds of a depside, depsidone, dibenzofuran and polysaccharide structure were characterized by the significant anti-inflammatory activity, resulting, among others, from the ability to inhibit enzymes involved in the course of inflammation including cyclooxygenase, lipoxygenase, and prostaglandin synthase. The biological lichen properties, observed in numerous experiments, conducted at different research centers and performed using various methods, allow for the conclusion that these underestimated so far organisms are an attractive material for further work, the results of which may be useful in the production of various preparations.

Ethical approval: The conducted research is not related to either human or animal use.

Conflict of interest: Authors declare no conflict of interest.

\section{REFERENCES}

1. Dawid-Pać R. Fitoterapia schorzeń dermatologicznych. In: Nowak G., ed. Leki pochodzenia naturalnego. 1st ed. Poznań. Wydawnictwo Naukowe UMP, 2012:296-339.

2. Studzińska-Sroka E, Galanty A, Bylka W. Atranorin - an interesting lichen secondary metabolite. Mini Rev Med Chem 2017; 17(17):16331645. doi: http://dx.doi.org/10.2174/1389557517 666170425105727

3. Xu M, Heidmarsson S, Olafsdottir ES, Buonfiglio R, Kogej T, Omarsdottir S. Secondary metabolites from cetrarioid lichens: Chemotaxonomy, biological activities and pharmaceutical potential. Phytomedicine 2016; 23(5):441-59. doi: http:// dx.doi.org/10.1016/j.phymed.2016.02.012

4. Studzińska E, Witkowska-Banaszczak E, Bylka W. Związki biologicznie czynne porostów. Herba Pol 2008; 54(1):79-88.

5. Bugni TS, Andjelic CD, Pole AR, Rai P, Ireland CM, Barrows LR. Biologically active components of a Papua New Guinea analgesic and anti-in- 
flammatory lichen preparation. Fitoterapia 2009; 80(5):270-3. doi: http://dx.doi.org/10.1016/j.fitote.2009.03.003

6. Kumar S, Müller K. Lichen metabolites. 1. Inhibitory action against leukotriene B4. Biosynthesis by a non-redox mechanism. J Nat Prod 1999; 62(6):817-820.

7. Ingolfsdotiir $\mathrm{K}$, Gissurarson SR, Moller-Jakic $\mathrm{B}$, Breu W, Wagner $\mathrm{H}$. Inhibitory effects of the lichen metabolite lobaric acid on arachidonate metabolism in vitro. Phytomedicine 1996; 2(3):243-246.

8. Melo MG, de Souza Araújo AA, Serafini MR, Carvalho LF, Bezerra MS, Ramos CS et al. Antiinflammatory and toxicity studies of atranorin extracted from Cladina kalbii Ahti in rodents. Braz J Pharm Sci 2011;47(4):861-872. doi: http:// dx.doi.org/10.1590/S1984-82502011000400024

9. Umezawa H, Shibamoto N, Naganawa H, Ayukawa S, Matsuzaki $M$, Takeuchi $\mathrm{T}$ et al. Isolation of lecanoric acid, an inhibitor of histidine decarboxylase from a fungus. J Antibiot (Tokyo) 1974; 27(8):587-596.

10. Kumar SKC, Müller K. Depsides as non-redox inhibitors of leukotriene B4 biosynthesis and $\mathrm{HaCaT}$ cell growth. 1. Novel analogues of barbatic and diffractaic acid. Eur J Med Chem 1999; 35(4):1035-1042.

11. Sankawa U, Shibuya M, Ebizuka Y Noguchi H, Kinoshita T, Iitaka Y et al. Depside as potent inhibitor of prostaglandin biosynthesis: a new active site model for fatty acid cyclooxygenase. Prostaglandins 1982; 24(1):21-34.

12. Luz JG, Antonysamy S, Kuklish SL, Condon B, Lee MR, Allison D et al. Crystal structures of mPGES-1 inhibitor complexes form a basis for the rational design of potent analgesic and anti-inflammatory therapeutics. J Med Chem 2015; 58(11):4727-4737. doi: http://dx.doi. org/10.1021/acs.jmedchem.5b00330

13. Bauera J, Waltenbergerb B, Nohac SM, Schusterc D, Rollingerb JM, Boustied J et al. Discovery of depsides and depsidones from lichen as potent inhibitors of microsomal prostaglandin E2 synthase-1 using pharmacophore models. Chem
Med Chem 2012; 7(12):2077-2081. doi: http:// dx.doi.org/10.1002/cmdc.201200345

14. Oettl SK, Gerstmeier J, Khan SY, Wiechmann K, Bauer J, Atanasov AG et al. Imbricaric acid and perlatolic acid: multi-targeting anti-inflammatory depsides from Cetrelia monachorum. PLoS One 2013; 8(10). doi: http://dx.doi.org/10.1371/ journal.pone.0076929

15. Araújo AA, de Melo MG, Rabelo TK, Nunes PS, Santos SL, Serafini MR et al. Review of the biological properties and toxicity of usnic acid. Nat Prod Res 2015; 29(23):2167-80. doi: http:// dx.doi.org/10.1080/14786419.2015.1007455

16. Huang Z, Tao J, Ruan J, Li C, Zheng G. Antiinflammatory effects and mechanisms of usnic acid, a compound firstly isolated from lichen Parmelia saxatilis. J Med Plant Res 2014; 8(4):197-207. doi: http://dx.doi.org/10.5897/ JMPR10.873

17. Vijayakumar CS, Viswanathan S, Kannappa Reddy M, Parvathavarthini S, Kundu AB, Sukumar E. Anti-inflammatory activity of (+)-usnic acid. Fitoterapia 2000; 71(5):564-566.

18. Su ZQ, Mo ZZ, Liao JB, Feng XX, Liang YZ, Zhang $\mathrm{X}$ et al. Usnic acid protects LPS-induced acute lung injury in mice through attenuating inflammatory responses and oxidative stress. Int Immunopharmacol 2014; 22(2):371-8. doi: http://dx.doi.org/10.1016/j.intimp.2014.06.043.

19. Shrestha G, St Clair LL, O’Neill KL. The immunostimulating role of lichen polysaccharides: a review. Phytother Res 2015; 29(3):317-22. doi: http://dx.doi.org/10.1002/ptr.5251

20. Omarsdottir S, Freysdottir J, Barsett H, Paulsen BS, Olafsdottir ES. Effects of lichen heteroglycans on proliferation and IL-10 secretion by rat spleen cells and IL-10 and TNF-alpha secretion by rat peritoneal macrophages in vitro. Phytomedicine 2005; 12(6-7):461-7.

21. Omarsdottir S, Freysdottir J, Olafsdottir ES. Immunomodulating polysaccharides from the lichen Thamnolia vermicularis var. subuliformis. Phytomedicine 2007; 14(2-3):179-84. doi: http:// dx.doi.org/10.1016/j.phymed.2006.11.012 
22. Molnár K, Farkas E. Current results on biological activities of lichen secondary metabolites: a review. Z Naturforsch C 2010; 65(3-4):157-173. doi: http://dx.doi.org/10.1515/znc-2010-3-401

23. Güvenç A, Küpeli Akkol E, Süntar I, Keleş H, Yıldız S, Calış I. Biological activities of Pseudevernia furfuracea (L.) Zopf extracts and isola- tion of the active compounds. J Ethnopharmacol 2012; 144(3):726-734. doi: http://dx.doi. org/10.1016/j.jep.2012.10.021

24. Jain AP, Bhandrkar S, Rai G, Yadav AK, Lodhi S. Evaluation of Parmotrema reticulatum Taylor for antibacterial and antiinflammatory activities. Indian J Pharm Sci 2016; 78(1):94-102.

\title{
Porosty jako źródło związków o działaniu przeciwzapalnym
}

\author{
ELŻBIETA STUDZIŃSKA-SROKA*, ADRIANNA DUBINO
}

Katedra i Zakład Farmakognozji

Uniwersytet Medyczny im. K. Marcinkowskiego w Poznaniu

ul. Święcickiego 4

60-781 Poznań

*autor, do którego należy kierować korespondencję: ela_studzinska@op.pl

\section{Streszczenie}

Objawy zapalenia towarzyszą wielu jednostkom chorobowym. W celu ich łagodzenia medycyna ludowa wykorzystuje różnorodne substancje lecznicze, w tym zioła i grzyby. Porosty stanowią grupę organizmów mniej znanych, lecz zawierających specyficzne metabolity wtórne o ciekawych właściwościach biologicznych. Jednym z kierunków działania porostów, potwierdzonym badaniami w warunkach in vitro i na zwierzętach, jest aktywność przeciwzapalna. Dowiedziono, że związki i wyciągi z porostów działają m.in. poprzez hamowanie enzymów uczestniczących w przebiegu procesu zapalnego. Artykuł stanowi przegląd badań nad mało znanymi przeciwzapalnymi właściwościami porostów.

Słowa kluczowe: związki porostowe, wyciagi porostowe, aktywność biologiczna 